\title{
PERANCANGAN ANIMASI TENTANG SOSIALISASI KEMBALI BERSEKOLAH BAGI ANAK DI PASCA PANDEMI MENGGUNAKAN TEKNIK MOTION GRAPHIC
}

\author{
Ristia Kadiasti ${ }^{1}$, Mukaromah ${ }^{2}$ \\ ${ }^{1}$ Animasi, Fakultas IImu Komputer, Universitas Dian Nuswantoro Semarang \\ ${ }^{2}$ Ilmu Komunikasi, Fakultas Ilmu Komputer, Universitas Dian Nuswantoro Semarang \\ ristiakadiasti@dsn.dinus.ac.id ${ }^{1}$, mukaromah@dsn.dinus.ac.id ${ }^{2}$
}

\begin{abstract}
Abstrak
Dampak yang dirasakan akibat pandemi COVID-19 berpengaruh tidak hanya pada kondisi ekonomi namun juga psikologis khususnya pada anak-anak. Hal tersebut terlihat pada perkembangan proses belajar anak pada saat kegiatan belajar mengajar melalui media daring, seperti kesulitan berkonsentrasi, gelisah, dan rasa khawatir yang berlebihan. Kebutuhan untuk memotivasi anak-anak dalam menyerap pelajaran kembali menjadi sebuah hal yang mendesak ketika mereka akan kembali bersekolah secara tatap muka pasca pandemi nanti. Namun, sebelum menempatkan anak-anak ke dalam kondisi tersebut, perlu adanya sebuah program yang membekali anak-anak sebelum kegiatan berbasis kurikulum dilaksanakan. Penelitian ini menggunakan pengumpulan data dari penelitian program intervensi kembali bersekolah oleh Jhoni Warmansyah dan menggunakan metode perancangan dengan model SMCR (Source, Message, Channel, Receiver) yang kemudian menghasilkan media video infografis berbentuk motion graphic berupa sosialisasi dengan konten pesan membekali anak dalam mematuhi protokol kesehatan ketika kembali bersekolah. Animasi ini memberikan edukasi terkait pengenalan emosi anak pada masa pandemi dan juga memberikan pembekalan berupa demonstrasi tentang pematuhan protokol kesehatan pada anak-anak di saat mereka kembali bersekolah nanti.
\end{abstract}

Kata Kunci: anak, animasi, motion graphic, pandemi, sosialisasi

\begin{abstract}
The impact perceived due to the Covid-19 pandemic affects economic conditions and also psychologically, especially on children. This indication can be seen in the development of children's learning processes during teaching and learning activities through online media. Children sometimes feel difficulty concentrating, anxiety, and excessive worry. The need to motivate children to absorb lessons again becomes an urgent matter when they return to school face to face after the pandemic. However, before placing children into this condition, it is necessary to have a program that equips children before implementing the activities. This study uses data collected from the back-to-school intervention program research by Jhoni Warmansyah along with the SMCR model that later can produce infographic video media in the form of motion graphics. This animation provides education regarding the introduction of children's emotions during the pandemic and further provides instruction in the form of demonstrations on compliance with health protocols for children when they return to school later.
\end{abstract}

Keywords: child, animation, campaign, motion graphic, pandemic 


\section{PENDAHULUAN}

Selama pandemi COVID-19 yang melanda global termasuk Indonesia, penyesuaian perilaku terjadi dalam banyak aspek termasuk dalam aspek pendidikan yang mengharuskan anak sekolah belajar secara daring dari rumah. Awal masa pandemi, pembelajaran daring menjadi solusi sementara yang masuk akal di tengah penularan virus COVID-19 yang sangat cepat agar peserta didik tidak tertinggal dalam bidang pendidikan. Namun seiring dengan lamanya waktu karantina, hal ini menimbulkan problem tersendiri dalam pembelajaran model daring jarak jauh ini. Problematik tersebut mengacu pada pembelajaran daring, dimana pola asuh orang tua sangat berperan dalam mendidik anak di rumah karena peran orang tua dan tingkat sensitifitas orang tua berpengaruh terhadap tingkah laku anak (Cahyati \& Kusumah, 2020).

Ppenelitian yang dilakukan oleh Ghosh (2021) bahwa pandemi COVID-19 memiliki kerugian bagi anak-anak baik fisik ataupun mental karena meningkatnya tingkat stress orang tua atau pengasuh anak-anak tersebut dari berbagai latar belakang seperti berkurangnya pendapatan, kehilangan anggota keluarga, dan isolasi sosial. Sensitifitas orang tua tersebut akhirnya berdampak pada kesehatan mental anak-anak. Penelitian tersebut juga menyimpulkan bahwa isu kesehatan mental anak-anak tersebut bisa menjadi efek buruk jangka panjang bagi anak-anak dan perlu adanya bimbingan dan kesadaran tentang masalah psikologi baik dari orang tua, tenaga kesehatan, ataupun sekolah.

Hal tersebut juga didiukung oleh penelitian yang telah dilakukan terkait program intervensi kembali bersekolah oleh Warmansyah (2020), menyebutkan bahwa peningkatan resiko paparan anak terhadap kekerasan keluarga dapat terjadi selama periode krisis karena kondisi orang tua yang dipaksa untuk memenuhi tuntutan pekerjaan sambal merawat dan mendidik anak mereka di rumah dan juga masalah finansial, logistik, dan eksistensial yang menjadi pemicu meluapnya emosi orang tua yang berdampak pada anak-anak.

Beberapa wacana tentang proses belajar mengajar secara tatap muka mulai diumumkan, salah satunya keputusan dari Menteri Pendidikan, Nadiem Makarim, pada 7 Agustus 2020 sebagaimana dikutip pada BBC News Indonesia (2020) yaitu kembali membuka kesempatan sekolah dengan tatap muka meskipun dengan syarat khusus taat pada protokol kesehatan. Hal ini mengingat dengan banyaknya keluhan dari efek pembelajaran daring dan situasi yang belum lepas dari kondisi pandemik. Lebih lanjut sebagaimana dikutip pada liputan6.com pada 26 November 2020 tentang Pembukaan kembali sekolah-sekolah di semua zona di Indonesia dengan ketentuan protokol kesehatan. Hal ini juga turut membawa serta kesiapan anak-anak dalam mengembalikan motivasi belajar dan ketertinggalan penyerapan materi yang dilaksanakan selama belajar daring (Harsono, 2020). Meskipun hal tersebut masih harus mengikuti kondisi masing-masing zona yang tidak menentu, seiring berjalannya waktu anak-anak ini nantinya tetap akan melaksanakan kegiatan belajar mengajar di sekolah ketika kondisi mulai membaik. Pembekalan kepada anak-anak tentang bagaimana mereka mampu 
beradaptasi dengan protokol kesehatan dan berinteraksi baik dengan guru atau teman perlu disosialisasikan.

Media penyampaian sosialisasi tersebut harus mampu menyampaikan informasi secara jelas dan informatif mengenai bagaimana cara anak-anak menerapkan protokol kesehatan dan bagaimana cara mereka berinteraksi dengan orang lain di luar rumah. Media penyampaian informasi tersebut yaitu menggunakan media infografis. Infografis, dari kata informasi dan grafis, merupakan proses penyerderhanaan informasi dan meningkatkan proses serapan data kepada khalayak sehingga lebih mudah untuk dimengerti (Damyanov \& Tsankov, 2018). Kebutuhan sosialisasi dengan banyaknya informasi dan penjelasan prosedur protokol kesehatan tersebut akan lebih mudah dimengerti dengan penyajian dalam bentuk infografis.

Penyampaian infografis tersebut kemudian disesuaikan dengan kebutuhan dan sasaran. Dalam penelitian ini, model SMCR digunakan sebagai acuan menentukan media dan efektifitasnya ke dalam sasaran komunikan. SMCR merupakan akronim dari SourceMessage-Channel-Receiver yang dikemukakan oleh David K. Berlo yang menekankan komunikasi lebih kepada pemaknaan yang ada pada pesan yang disampaikan dari komunikator ke komunikan. Konsep komunikasi tersebut, memfokuskan pada bagian Message (Pesan) dan Channel (Saluran). Hal tersebut dikemukakan oleh Tim Pengembang IImu Pendidikan UPI yang menjadi dasar penelitian ini untuk mengembangkan proses komunikasi berbasis audio visual, dimana implementasi dari komunikasi ini merupakan munculnya timbal balik dari penyampaian informasi dari komunikator ke komunikan dalam proses memberlakukan pesan (Haryadi, 2018).

Pada Channel yaitu media saluran pesan, mengacu pada komunikasi yang melibatkan 5 (lima) sistem indra tubuh manusia untuk dapat menyampaikan pesan secara efektif. Pada penelitian ini, komunikasi berbasis audio visual tersebut diwujudkan dalam bentuk animasi motion graphic, dimana animasi motion graphic mampu meningkatkan motivasi, partisipasi, dan keingintahuan murid di Indonesia seperti dibuktikan pada penelitian yang dilakukan oleh Amali, Zees, \& Suhada (2020) yang menemukan bahwa perbedaan rata-rata prestasi belajar siswa setelah pemanfaatan materi pembelajaran berbasis video animasi motion graphic adalah $(79,20)$ dibandingkan sebelum pemanfaatan media tersebut $(57,60)$ dalam pembelajaran.

Melalui media animasi motion graphic, penelitian ini bertujuan untuk mampu memberi edukasi dan sosialisasi terkait persiapan siswa untuk masuk sekolah sebelum proses belajar mengajar berbasis kurikulum berlangsung pada pasca pandemi Covid-19. Hal ini terkait dengan kebutuhan siswa dalam transisi dan adaptasi kembali ke dalam proses belajar mengajar di pasca pandemi dan mengingatkan siswa dalam mematuhi protokol kesehatan. Perancangan ini mengacu pada penelitian animasi edukasi yang lain yaitu Yusa \& Rukmi ( 2017); Anggelina \& Trisnadoli (2020); dan Putra, Santosa, \& Setiawan (2019). Penelitian yang sebelumnya belum ada yang meneliti perancangan animasi edukasi untuk anak tentang pandemi di lingkungan sekolah. 


\section{METODE PENELITIAN}

\subsection{Pendekatan Penelitian}

Penelitian ini menggunakan acuan tabel intervensi kembali bersekolah yang merupakan hasil penelitian dari Warmansyah (2020), yang menghasilkan beberapa kegiatan untuk anak-anak sebelum kegiatan belajar mengajar berbasis kurikulum diadakan secara tatap muka di sekolah. Tabel tersebut menggunakan strategi Koping yang dapat membangun ketahanan (resiliensi) pada anak dimana proses resiliensi tersebut mampu untuk mengembalikan stabilitas atau keadaan selama anak-anak melakukan karantina di rumah pada masa pandemi. Tabel tersebut berisi kegiatan dan panduan yang dilakukan oleh anak-anak sebelum implementasi kegiatan belajar tatap muka dimulai dengan dipandu oleh orang tua atau guru. Cakupan tabel kegiatan tersebut meliputi tujuan, aktivitas, alasan, dan dimensi intervensi yang akan diterapkan kepada anak-anak. Lihat Tabel 1.

Tabel tersebut kemudian dijadikan sebagai konten pesan yang digabungkan dengan pendekatan SMCR. Metode penelitian yang digunakan dalam perancangan animasi motion graphic sebagai bekal anak-anak kembali ke sekolah yaitu menggunakan pendekatan SMCR atau source, message, channel, and receiver. Metode ini disampaikan oleh David K. Berlo, dimana pada dasarnya model komunikasi ini memusatkan pada proses komunikasi dengan penekanan penafsiran komunikasi pada kata dan gerak tubuh penyampai pesan dan penerima pesan. Proses komunikasi dikemukakan dalam kode simbolik, dengan melalui medium pembawa pesan oleh komunikator dan penerima pesan yang menjadi sasaran komunikasi atau komunikan. Komunikasi pada anak membutuhkan modifikasi bentuk yang ada saat ini agar dapat bersinergi dengan perkembangan teknologi saat ini seperti menggunakan media audio visual (Senoprabowo, Khamadi, \& Laksana, 2018).

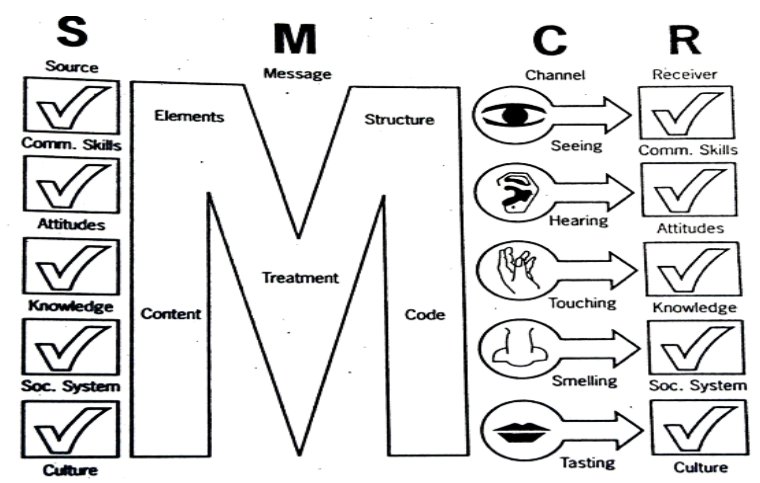

Gambar 1. Model Komunikasi SMCR oleh David K. Berlo [Sumber : Mulyana (2007)]

Acuan tersebut yang merupakan titik berat dari segi message (pesan) dan channel (saluran) yang ada dalam pendekatan SMCR. Penerapan komunikasi SMCR ke dalam penelitian ini memiliki peran yang signifikan dimana message (pesan) dan channel (saluran) menggunakan media penyampaian yang mendukung peran aktif siswa dalam tersalurkannya pesan yang akan disampaikan. Dimana hal tersebut berkaitan dengan aspek indrawi anak yang tertera pada channel (saluran) pada model komunikasi SMCR. 


\subsection{Metode Perancangan}

Dalam setiap proses perancangan sebuah video dibutuhkan serangkaian tahapan dengan berbagai proses yang menyesuaikan luaran dari perancangan. Pada penelitian ini, luaran yang akan dihasilkan adalah animasi motion graphic yang memiliki tiga tahapan yang disebut dengan pipeline yaitu proses pra produksi, produksi dan pasca produksi.

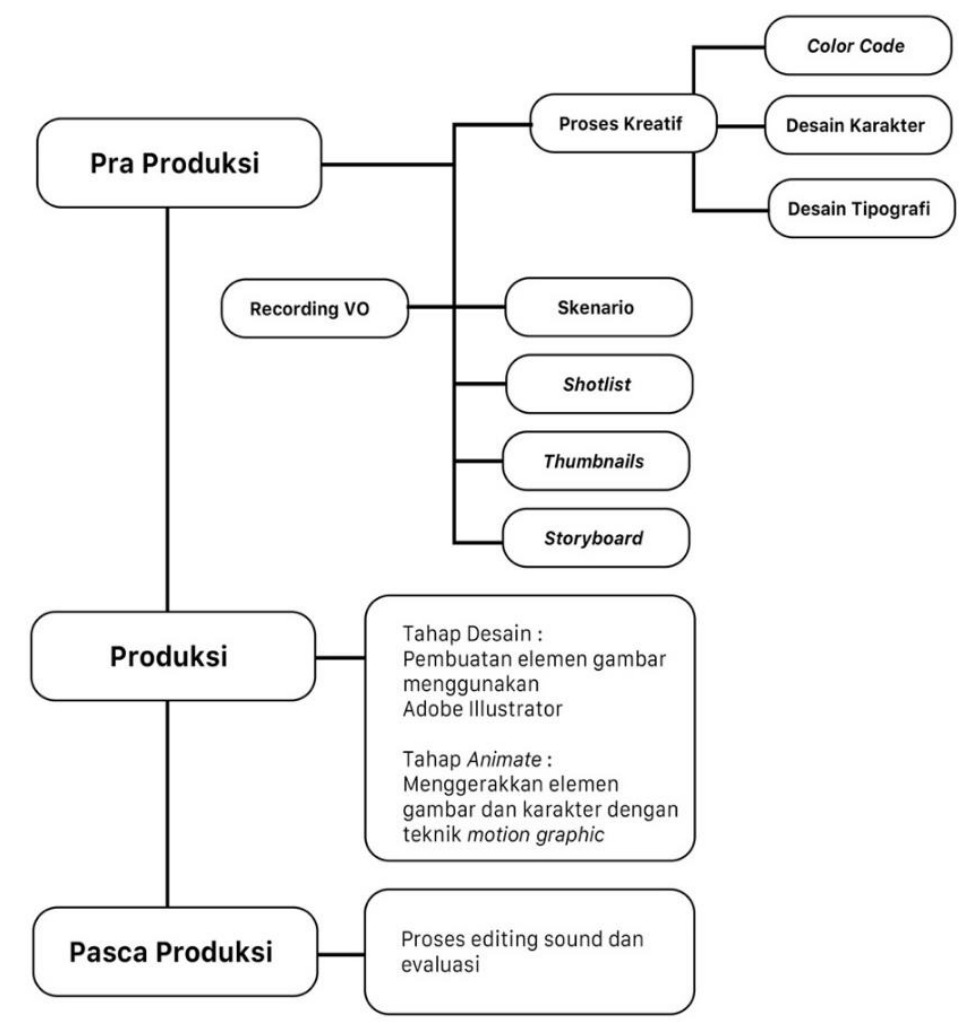

Gambar 2. Bagan Metode Perancangan dalam Tiga Tahapan Pipeline [Sumber: Dokumentasi Penulis]

\section{HASIL DAN PEMBAHASAN}

\subsection{Pemetaan Konsep Pesan Sosialisasi}

Perancangan ini berpusat pada proses pra produksi dan produksi dimana pada proses tersebut membutuhkan pematangan konsep pada pesan dan visualisasi sesuai dengan acuan dari perancangan ini yaitu hasil penelitian dalam tabel 1 tabel program intervensi kembali ke sekolah yang dilakukan oleh Warmansyah (2020) dengan message (pesan) dan channel (saluran) yang ada pada model SMCR.

Tabel 1. Tabel Program Intervensi Kembali Bersekolah oleh Jhoni Warmansyah [Sumber : Warmansyah, 2020]

\begin{tabular}{|l|l|l|l|}
\hline \multicolumn{1}{|c|}{ Tujuan } & \multicolumn{1}{|c|}{ Aktivitas } & \multicolumn{1}{c|}{ Alasan } & Dimensi Intervensi \\
\hline $\begin{array}{l}\text { Membangkitkan } \\
\text { kesadaran anak akan } \\
\text { diri sendiri dan orang } \\
\text { lain di sekitar mereka. }\end{array}$ & $\begin{array}{l}\text { Mengembalikan } \\
\text { memori tentang } \\
\text { kegiatan anak-anak } \\
\text { selama di sekolah }\end{array}$ & $\begin{array}{l}\text { Pengembangan } \\
\text { perasaan diri melalui } \\
\text { eksplorasi } \\
\text { lingkungan }\end{array}$ & $\begin{array}{l}\text { Aspek sosial dan } \\
\text { emosi anak }\end{array}$ \\
\hline
\end{tabular}




\begin{tabular}{|l|l|l|l|}
\hline \multicolumn{1}{|c|}{ Tujuan } & \multicolumn{1}{c|}{ Aktivitas } & \multicolumn{1}{c|}{ Alasan } & Dimensi Intervensi \\
\hline $\begin{array}{l}\text { Mengenal emosi } \\
\text { sebagai hal yang wajar } \\
\text { dialami oleh anak- } \\
\text { anak kaitannya } \\
\text { dengan resistansi } \\
\text { mental anak saat } \\
\text { pandemi }\end{array}$ & $\begin{array}{l}\text { Mengenalkan } \\
\text { berbagai emosi anak } \\
\text { ketika anak belajar di } \\
\text { rumah }\end{array}$ & $\begin{array}{l}\text { Sebagai upaya } \\
\text { mencerna emosi } \\
\text { yang berhubungan } \\
\text { dengan kondisi anak } \\
\text { yang membuat } \\
\text { stress }\end{array}$ & $\begin{array}{l}\text { Proses pengenalan } \\
\text { emosi anak }\end{array}$ \\
\hline $\begin{array}{l}\text { Menambah } \\
\text { kepercayaan anak } \\
\text { pada orang dewasa } \\
\text { baik di rumah maupun } \\
\text { di sekolah }\end{array}$ & $\begin{array}{l}\text { Kegiatan } \\
\text { pemrosesan emosi } \\
\text { anak dengan } \\
\text { meminta mereka } \\
\text { untuk membantu } \\
\text { mengidentifikasi } \\
\text { perasaan kepada } \\
\text { orang tua atau guru }\end{array}$ & $\begin{array}{l}\text { Proses } \\
\text { mengungkapkan } \\
\text { pikiran dengan orang } \\
\text { lain dapat } \\
\text { membantu anak- } \\
\text { anak mengenali cara } \\
\text { menangani kondisi } \\
\text { dan mau } \\
\text { mengungkapkannya } \\
\text { kepada orang lain }\end{array}$ & keluarga \\
anak kepada \\
kematif \\
\hline $\begin{array}{l}\text { Membuat anak-anak } \\
\text { untuk mampu } \\
\text { melakukan tindakan } \\
\text { pencegahan } \\
\text { penularan }\end{array}$ & $\begin{array}{l}\text { Demonstrasi tentang } \\
\text { pentingnya protokol } \\
\text { kesehatan untuk } \\
\text { diterapkan saat } \\
\text { kembali bersekolah }\end{array}$ & $\begin{array}{l}\text { Memberi } \\
\text { pemahaman kepada } \\
\text { anak-anak untuk } \\
\text { menerapkan gaya } \\
\text { hidup sehat sejak } \\
\text { awal }\end{array}$ & Proses kognitif dan \\
\hline
\end{tabular}

Penelitian ini menitikberatkan pada pesan pengenalan emosi anak dan demonstrasi tentang penerapan protokol kesehatan yang berguna untuk pembekalan anak ketika kembali bersekolah nanti. Hal tersebut terpetakan dalam pemetaan konten pesan dalam model SMCR berikut:
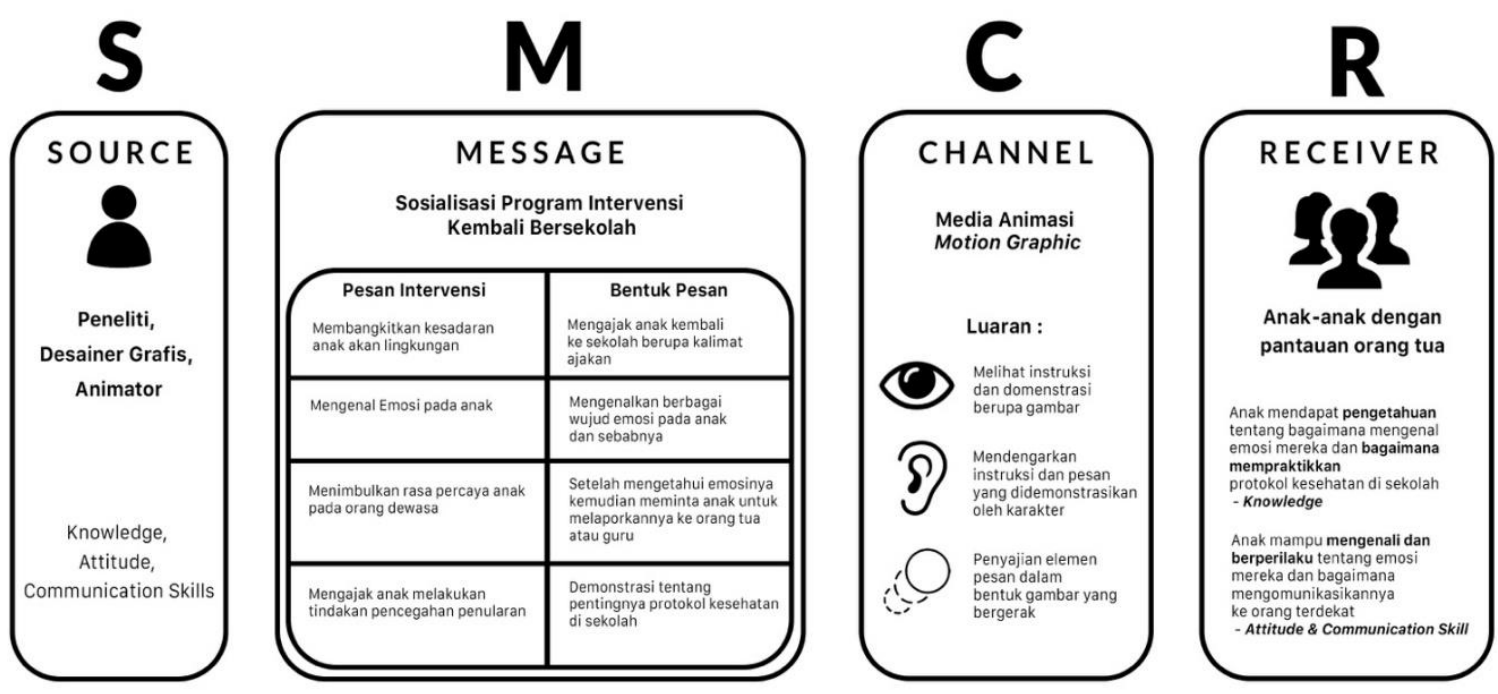

Gambar 3. Pemetaan Konten Tabel Program Intervensi Kembali Bersekolah dalam Model SMCR [Sumber: Dokumentasi Penulis] 
Source dalam SMCR merupakan sumber penyampai pesan yang memiliki kemampuan komunikasi, dalam penelitian ini yang berlaku sebagai source adalah konseptor, desainer grafis, juga animator pembuat animasi motion graphic ini. Message merupakan pesan yang ada pada media tertentu. Dalam penelitian ini pesan yang disampaikan baik verbal ataupun nonverbal yang disajikan berhubungan dengan protokol kesehatan saat kembali bersekolah yang ditujukan untuk anak-anak.

Channel merupakan media input/output pesan yang berkaitan dengan aspek inderawi, yaitu mata, telinga, hidung, mulut, dan sentuhan. Pada penelitian ini, dengan luaran media yang berbentuk audio visual yaitu dalam bentuk gabungan suara dan gambar infografis yang dapat dilihat dan dicerna bersamaan dengan teknik motion graphic. Animasi motion graphic ini nantinya akan disebarluaskan kepada peserta didik dan orang tua siswa melalui media sosial yang dimiliki sekolah untuk disebarkan ke seluruh siswa sebelum proses belajar mengajar secara tatap muka di sekolah dimulai. Receiver merupakan penerima pesan/user yang menangkap pesan dan memberikan umpan balik, dalam penelitian ini receiver atau penerima pesannya adalah anak anak peserta didik di level sekolah dasar yang akan kembali bersekolah agar saat bersekolah kembali mereka sadar dan taat protokol saat belajar dan berinteraksi di sekolah baik dengan teman, orang tua maupun guru.

\subsection{Proses Pra Produksi}

Tahapan dalam proses pra produksi mencakup proses pembuatan skenario, shotlist, thumbnails, dan storyboard. Selain itu, di dalam proses pra produksi terdapat proses kreatif yang meliputi perancangan desain karakter, perancangan tipografi, dan penentuan color code. Perancangan desain karakter untuk mendukung penyajian demonstrasi dan instruksi yang ada dalam konten pesan. Perekaman VO (voice over) dilaksanakan bersamaan dengan proses pembuatan thumbnails dan storyboard.

\subsubsection{Konsep Desain Karakter}

Berdasarkan hasil wawancara dan kuesioner yang dikumpulkan, perancangan ini mengerucut pada target audience yaitu anak-anak usia 6-9 tahun yang duduk di kelas 1 hingga 3 bangku sekolah dasar menggunakan karakter seorang anak laki-laki dan perempuan bernama Ari dan Ira. Pemilihan nama karakter menggunakan pola asonansi yaitu menggunakan repetisi suara vokal yang bertujuan membuat sebuah rima internal pada satu frasa yang mempunyai fungsi memberikan deretan vokal dan bunyi konsonan. Pola asonansi tersebut mengambil komponen vokal yang mirip dan terbatas yaitu kurang dari suku kata (Amin \& Muliadi, 2016). Nama karakter tersebut menggunakan repetisi vokal [i] dan [a] dengan pola konsonan akan diletakkan di antara pola asonansi yaitu [r]. Pola tersebut disesuaikan dengan nama-nama yang sering digunakan di Indonesia dan disesuaikan dengan gender karakter, maka akan menjadi nama karakter Ira untuk perempuan dan Ari untuk laki-laki. 


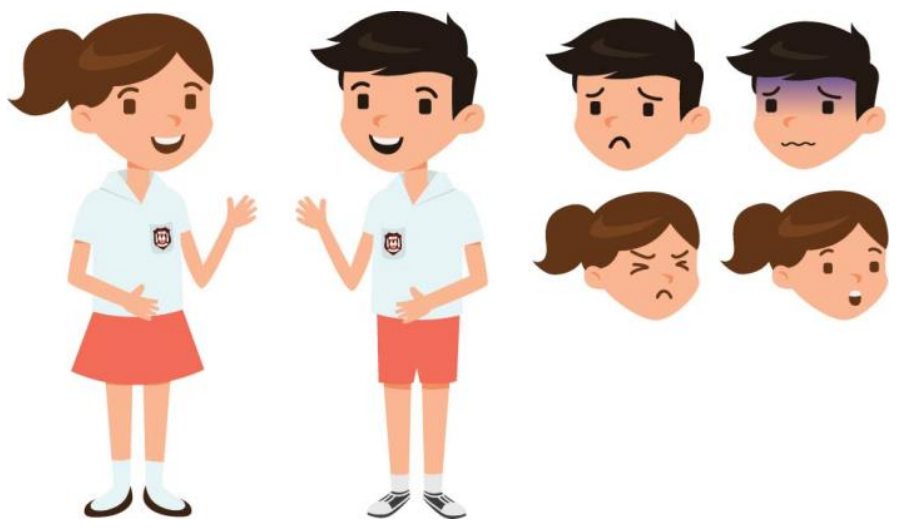

Gambar 4. Desain Karakter Ari dan Ira beserta Grafik Ekspresi Karakter

[Sumber: Dokumentasi Penulis]

\subsubsection{Thumbnails dan Storyboard}

Proses thumbnails merupakan konsep rancangan kasar sebelum memasuki penggambaran storyboard yang lebih kompleks. Proses ini untuk membantu memberikan gambaran bagaimana sudut pengambilan gambar yang dibutuhkan. Pada thumbnails sudah diberi penomoran berdasarkan nomor shot yang sudah dirancang pada penulisan skenario. Kemudian, thumbnails tersebut menjadi acuan pembuatan storyboard dengan detail adegan seperti penokohan, elemen gambar, dan dialog yang ada pada adegan tersebut.

Contoh Thumbnails Animasi Motion Graphic "Kembali ke Sekolah bersama Ari dan Ira"
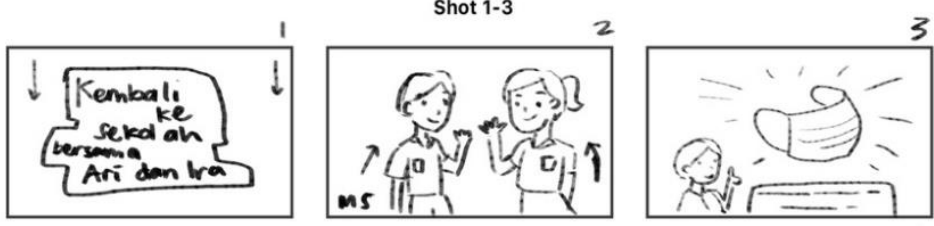

Contoh Storyboard Animasi Motion Graphic "Kembali ke Sekolah bersama Ari dan Ira" Scene 1 Shot 1 dan 2

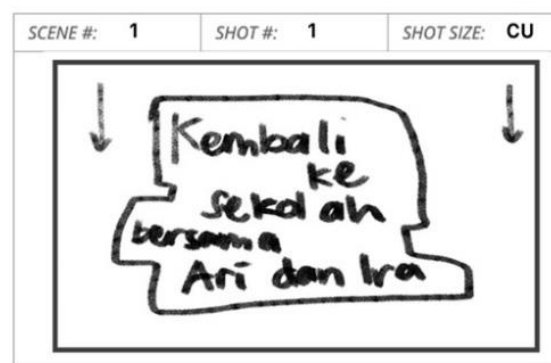

SCROLL UP TO DOWN - 00:03 Judul Teks muncul dari atas ke bawah

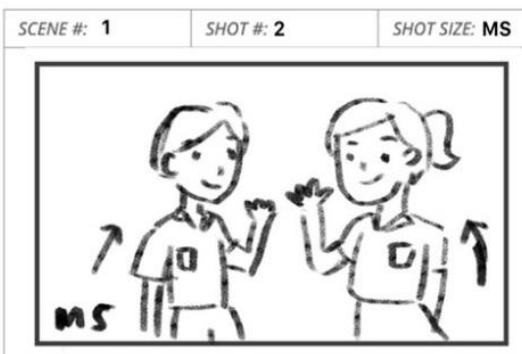

CHARACTER POP UP- 00:05

Ari dan Ira keluar dari bawah ke atas Ari : "Halo, namaku Ari" Ira : "dan aku Ira"

Gambar 5. Sampel Thumbnails dan Storyboard

[Sumber: Dokumentasi Penulis]

\subsubsection{Konsep Tipografi}

Tipografi yang terdapat dalam animasi motion graphic ini memiliki peran yang tidak kalah penting, karena banyaknya elemen tipografi dalam bentuk subtitle dan judul pada pembuka video. Elemen tipografi tersebut memiliki kontribusi yang krusial khususnya 
pada demonstrasi yang dilakukan oleh karakter mengenai kesiapan anak-anak pasca pandemi di lingkungan sekolah. Karakteristik font yang dipilih harus disesuaikan dengan target audience yaitu usia 6 hingga 9 tahun. Maka dari itu, dibutuhkan jenis tipografi yang sederhana namun bersahabat. Bentuk font tersebut adalah Arial Rounded yang memiliki counter yang bulat dan terbuka pada setiap sisi huruf. Jenis font yang bulat dan terbuka tersebut memudahkan anak-anak dalam membaca (Setiautami, 2011).

\section{Arial Rounded $\mathrm{Aa} \mathrm{Bb} \mathrm{Cc}$

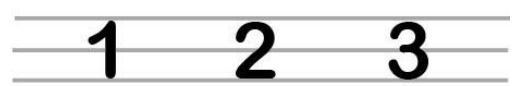

Gambar 6. Font Arial Rounded menjadi Font Pilihan yang Disesuaikan dengan Target Audiens

[Sumber: Dokumen Penulis]

\subsubsection{Konsep Warna}

Pada konsep warna, perancangan ini mengambil sampel kode warna yang digunakan pada film-film animasi dengan target audience serupa yaitu 6-9 tahun. Kemudian sampel film tersebut dikerucutkan lagi dengan film yang memiliki tema edukatif dan memberikan persuasi positif kepada anak-anak. Maka kode warna mengambil sampel video animasi dari Pinkfong Baby Shark Series dengan mengambil sampel warna dominan dan mengembangkannya menjadi beberapa kode warna sesuai dengan jumlah shot yang dibutuhkan.

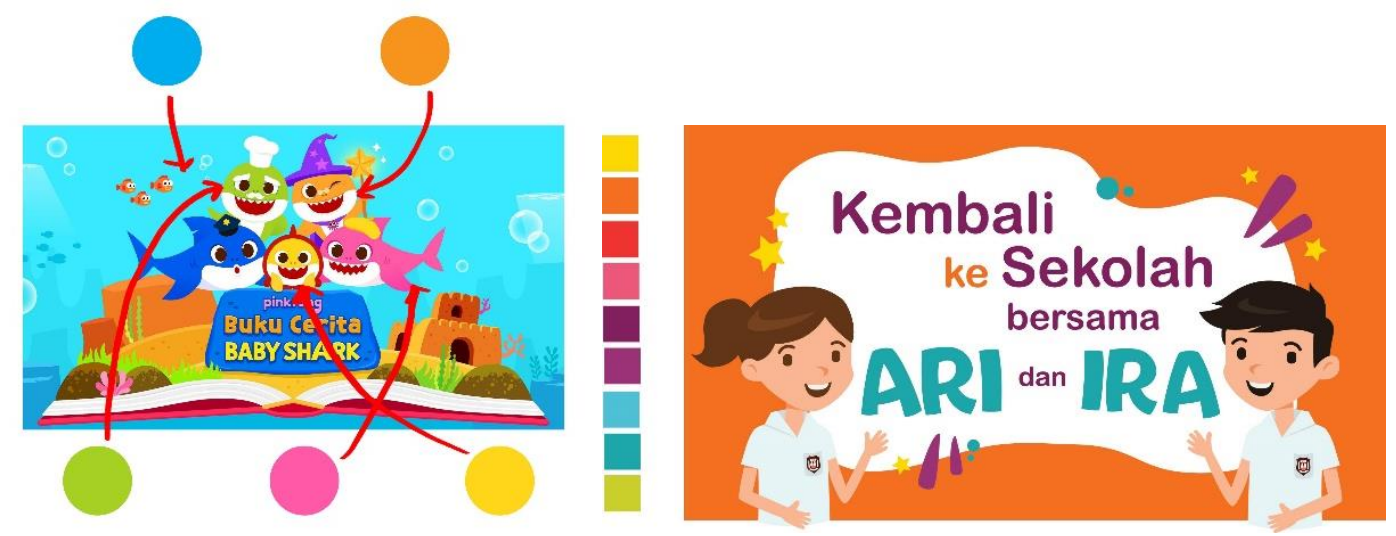

Gambar 7. Sampel Warna dari Pinkfong Baby Shark Series ke dalam Kode Warna Animasi Infografis [Sumber: Dokumen Penulis]

\subsection{Proses Produksi}

Animasi motion graphic berdurasi 3 menit ini memiliki rasio 16:9 yang memungkinkan untuk disebarkan melalui media sosial. Sesuai dengan pemilihan warna yang telah diambil pada poin sebelumnya, warna yang diambil adalah warna Jingga, Hijau, Ungu dan Biru yang diletakkan pada latar belakang. Memisahkan warna ke dalam beberapa shot bertujuan untuk memudahkan anak-anak dalam mengingat pesan, dan mampu mendapatkan perhatian anak-anak pada pesan-pesan yang disampaikan dalam animasi motion graphic tersebut. 


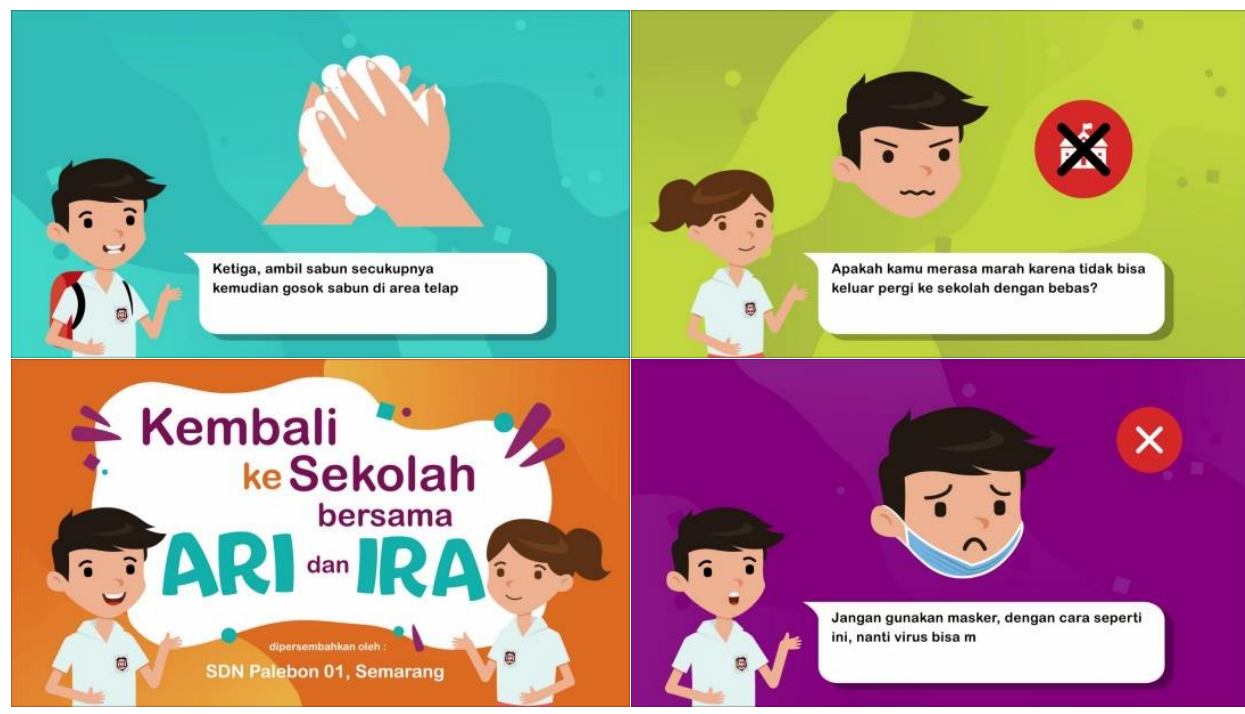

Gambar 8. Contoh screenshot dari Animasi Infografis

[Sumber: Dokumen Penulis]

Proses menggerakkan elemen gambar tersebut menggunakan teknik motion graphic dimana pada teknik tersebut, elemen grafis digerakkan untuk menghasilkan ilusi gerak dan modifikasi bentuk. Penggunaan motion graphic pada penelitian ini diharapkan mampu untuk memberi gambaran yang jelas terkait demonstrasi dan instruksi pesan yang disampaikan. Teknik motion graphic sendiri dipilih dengan dasar hasil penelitian yang dilakukan oleh Amali et all (2021) bahwa melalui teknik motion graphic, proses pembelajaran dapat menambah minat, partisipasi dan prestasi belajar siswa karena implementasi pembelajaran dipadukan dengan elemen gambar yang bergerak tersebut mudah diserap oleh siswa.

\subsection{Proses Pasca Produksi}

Proses pasca produksi pada perancangan ini menitikberatkan pada editing audio dan musik latar pendukung animasi motion graphic. Elemen suara yang ada pada animasi motion graphic ini menggunakan perekaman Vo (voice over) untuk suara dari karakter Ari dan Ira. Proses selanjutnya adalah proses rendering untuk menghasilkan video animasi yang siap untuk ditonton dan didistribusikan ke target audiens. Video animasi yang dihasilkan dirender dalam format MP4 dengan resolusi Full HD 720p.

\section{KESIMPULAN}

Animasi motion graphic menjadi salah satu media penyampaian pesan yang bersifat edukatif yang memuat konten instruksional dan demonstrasi. Konten bermuatan pembelajaran edukatif ini penting disampaikan terlebih di masa pandemi, di mana akses informasi berupa internet dan media sosial menjadi yang utama sebagai alat penyebar informasi dan juga sarana pembelajaran dengan kondisi yang belum memungkinkan untuk proses pembelajaran secara tatap muka dimana penularan virus dapat terjadi. Melalui terciptanya perancangan ini diharapkan mampu untuk memberi edukasi terkait pengenalan emosi anak pada masa pandemi dan juga memberikan pembekalan berupa demonstrasi tentang pematuhan protokol kesehatan pada anak-anak di saat mereka akan kembali bersekolah di pasca pandemi nantinya. 


\section{DAFTAR PUSTAKA}

Amali, L. N., Zees, N., \& Suhada, S. (2020). Motion graphic animation video as alternative learning media. Jambura Journal of Informatics, 2(1), 23-30.

Amin, K., \& Muliadi, M. (2016). Asonansi Dalam Puisi'Membaca untuk Mengetahui'Karya Udin Palisuri. Tamaddun, 15(1), 1-4.

Anggelina, S., \& Trisnadoli, A. (2020). Analisis Efektivitas Pesan Film Animasi 3D Bahaya Rokok terhadap Perokok Aktif Remaja dan Dewasa. ANDHARUPA: Jurnal Desain Komunikasi Visual \& Multimedia, 6(1), 115-124.

BBC News Indonesia. (2020). Kurikulum darurat Covid-19 dan "membuka sekolah" di zona kuning, kebijakan terbaru Kemendikbud di tengah pandemi - BBC News Indonesia. Retrieved August 31, 2021, from https://www.bbc.com/indonesia/indonesia-53691985

Cahyati, N., \& Kusumah, R. (2020). Peran orang tua dalam menerapkan pembelajaran di rumah saat pandemi Covid 19. Jurnal Golden Age, 4(1), 152-159.

Damyanov, I., \& Tsankov, N. (2018). The role of infographics for the development of skills for cognitive modeling in education. International Journal of Emerging Technologies in Learning (iJET), 13(1), 82-92.

Ghosh, D. (2021). The Impact of the Covid-19 Pandemic on Children and Adolescents Mental Health: A Literature Review. Indonesian Journal of Global Health Research, 3(3), 281-288.

Harsono, F. H. (2020). Sekolah Tatap Muka Harus Penuhi Sarana Cuci Tangan hingga Akses Faskes Terdekat - Health Liputan6.com. Retrieved August 31, 2021, from liputan6.com website: https://www.liputan6.com/health/read/4419221/sekolah-tatap-muka-haruspenuhi-sarana-cuci-tangan-hingga-akses-faskes-terdekat

Haryadi, T. (2018). Adaptasi Teori Difusi-Inovasi Dalam Game "Yuk Benahi” Dengan Pendekatan Komunikasi SMCR. Jurnal Audience: Jurnal IImu Komunikasi, 1(1), $1-13$.

Mulyana, D. (2007). Ilmu Komunikasi Suatu Pengantar. Bandung: Remaja Rosdakarya.

Putra, I. W. D., Santosa, I., \& Setiawan, P. (2019). Perancangan Animasi 360o Relief Jataka Candi Borobudur bagi Remaja 16-18 Tahun. ANDHARUPA: Jurnal Desain Komunikasi Visual \& Multimedia, 5(1), 63-82.

Senoprabowo, A., Khamadi, K., \& Laksana, D. A. W. (2018). Perkembangan Mainan Warak Ngendog sebagai Mainan Tradisional Kota Semarang. Seminar Nasional Seni Dan Desain 2018, pp. 149-156. Indonesia.

Setiautami, D. (2011). Eksperimen Tipografi dalam Visual untuk Anak. Humaniora, 2(1), 311-317.

Warmansyah, J. (2020). Program Intervensi Kembali Bersekolah Anak Usia Dini Masa Pandemi Covid-19. Jurnal Obsesi: Jurnal Pendidikan Anak Usia Dini, 5(1), 743.

Yusa, I. M. M., \& Rukmi, L. (2017). Video Edukasi Animasi 2 Dimensi Mengenai Bahaya Merkuri terhadap Masyarakat Kabupaten Lombok Tengah sebagai Dampak Penambangan Emas Ilegal. ANDHARUPA: Jurnal Desain Komunikasi Visual \& Multimedia, 3(2), 176-195. 